\title{
Spontaneous coronary artery dissection diagnosed by multislice computed tomography
}

Samoistne rozwarstwienie tętnicy wieńcowej rozpoznane za pomocą wielorzędowej tomografii komputerowej

\author{
Hakan Gunes ${ }^{1}$, Zekeriya Kucukdurmaz ${ }^{1}$, Emrah Seker², Recep Kurt'ㄹ, Ismail Salk², Hekim Karapınar ${ }^{1}$ \\ ${ }^{1}$ Cardiology Department, Cumhuriyet University Medical School, Sivas, Turkey \\ 2Radiology Department, Cumhuriyet University Medical School, Sivas, Turkey
}

Postep Kardiol Inter 2013; 9, 1 (31): 111-113

DOI: $10.5114 /$ pwki.2013.34038

\begin{abstract}
Spontaneous coronary artery dissection is a rare cause of acute coronary syndrome. Spontaneous coronary artery dissection can cause stable angina pectoris, unstable angina pectoris, acute myocardial infarction, cardiogenic shock and sudden cardiac death. It usually occurs in young to middle aged women. Atherosclerosis, peripartum period, and structural and inflammatory diseases affecting the artery wall are predisposing factors. It shows similar clinical presentation to coronary artery disease. Diagnosis and early treatment decrease mortality. Treatment options are medical treatment, percutaneous coronary intervention and surgery. The treatment decision is made according to the clinical presentation of the patient, the affected coronary artery and the length of the dissected segment. Diagnosis of the disease is usually made by coronary angiography. We present a patient who consulted our clinic with atypical chest pain and was diagnosed with spontaneous left anterior descending dissection by coronary computed tomography angiography.
\end{abstract}

Key words: spontaneous coronary artery dissection, computed tomography, angiography.

\section{Streszczenie}

Samoistne rozwarstwienie tętnicy wieńcowej jest rzadką przyczyną ostrego zespołu wieńcowego. Może ono prowadzić do stabilnej i niestabilnej choroby wieńcowej, ostrego zawału serca, wstrząsu kardiogennego oraz nagłego zgonu sercowego. Występuje zazwyczaj u kobiet w młodym lub średnim wieku. Do czynników sprzyjających wystąpieniu choroby należą: miażdżyca, okres okołoporodowy oraz choroby strukturalne i zapalne obejmujące ścianę tętnicy. Objawy tej choroby są podobne do objawów choroby wieńcowej. Rozpoznanie i wczesne leczenie pozwalają na zmniejszenie śmiertelności. Postępowanie obejmuje leczenie farmakologiczne, przezskórną interwencję wieńcową oraz operację. Decyzje terapeutyczne są podejmowane na podstawie obrazu klinicznego pacjenta, rodzaju rozwarstwionej tętnicy wieńcowej oraz długości rozwarstwionego odcinka. Rozpoznanie choroby ustala się zazwyczaj w trakcie koronarografii. W pracy przedstawiono przypadek pacjentki, którą przyjęto do kliniki z powodu nietypowego bólu w klatce piersiowej i u której na podstawie angiografii tomografii komputerowej rozpoznano samoistne rozwarstwienie gałęzi przedniej zstępującej.

Słowa kluczowe: samoistne rozwarstwienie tętnicy wieńcowej, tomografia komputerowa, angiografia.

\section{Introduction}

Spontaneous coronary artery dissection (SCAD) is a rare condition which can lead to acute coronary syndrome and sudden cardiac death [1, 2]. The first case of SCAD was documented in 1931 by Pretty [3] on an autopsy performed on a 42-year-old woman who presented with chest pain, and since then there have been many reported cases. As a result of a series of angiographies, the frequency is reported as $0.28-1.1 \%$. It is presumed that the true incidence is higher, as many cases are diagnosed postmortem. The disease usually occurs in young to middle aged women who are in the peripartum period and present no risk factors of

Corresponding author/Adres do korespondencji:

Zekeriya Kucukdurmaz MD, Cardiology Department, Cumhuriyet University Medical School, 58140, Sivas, Turkey, tel.: +905336122444, fax: +903462191115 , e-mail: trimesgites@hotmail.com

Received: 1.11.2012, accepted: 14.01.2013. 
atherosclerosis [1-4]. Coronary artery dissections can occur spontaneously or as a result of coronary angiography, coronary angioplasty, cardiac surgery procedures, blunt chest trauma or enlargement of aorta dissection. The diagnosis of SCAD can be made after elimination of all other causes of coronary artery dissection. The cases with SCAD are divided into three different groups: 1) patients with coronary artery disease, 2) young women in the late pregnancy or early postpartum period, 3) idiopathic group with undetected coronary artery disease risk factors $[2,5,6]$. Diagnosis of SCAD is usually made by coronary angiography.

\section{Aim}

We describe the case of a patient who came to our clinic with atypical chest pain and was diagnosed with spontaneous coronary artery disease by performing computed tomography coronary angiography, and the diagnosis of SCAD was confirmed by coronary angiography and treated with surgery.

\section{Case report}

A 54-year-old female patient referred to our cardiology clinic with recurring chest pain. According to the medical history, she had no complaints of blunt trauma or history of coronary angiography (CAG). She had no risk factors for coronary artery disease. In physical examination, the blood pressure was $110 / 80 \mathrm{~mm} \mathrm{Hg}$ and the pulse was $75 / \mathrm{min}$. The electrocardiography (ECG) results and the cardiac enzymes of the patient were normal. A treadmill exercise test was performed by the patient and it turned out to be positive. Computed tomography (CT) angiography was suggested to the patient, who showed a weakly positive treadmill exercise test but had no coronary risk factors. Contrast-enhanced CT coronary angiographic findings were compatible with linear hypodense demarcations which revealed an approximately $3.5 \mathrm{~cm}$ dissection line from the proximal

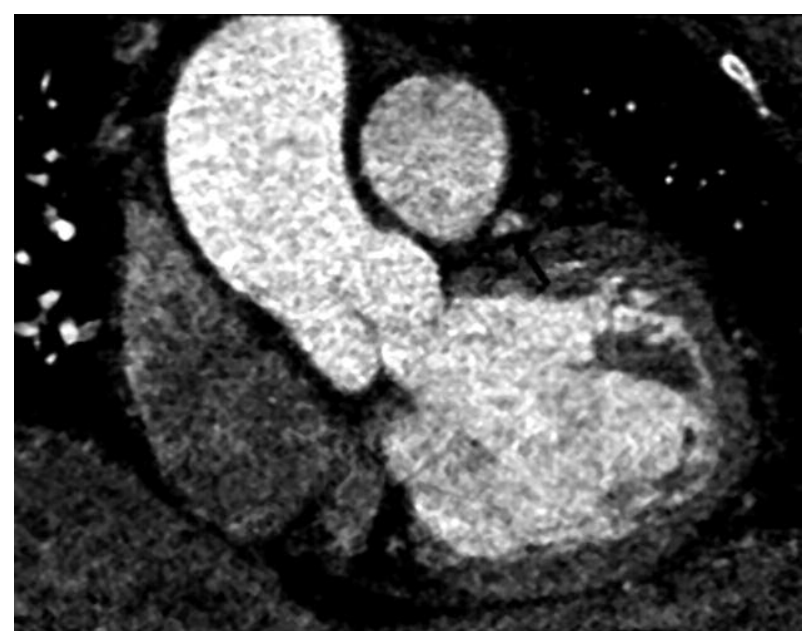

Fig. 1. Imaging of the left anterior descending dissection by computed tomography

Ryc. 1. Obraz rozwarstwienia gatęzi przedniej zstępującej $w$ tomografii komputerowej left anterior descending artery (LAD) to the second diagonal artery (Figure 1). Therefore coronary angiography was performed and the dissection line was detected in the indicated segment of the LAD (Figure 2). According to the evaluation of the patient, it was decided to perform a coronary artery bypass grafting operation (CABG). The patient was discharged after the CABG with medical therapy.

\section{Discussion}

In most cases (70-75\%), the clinical presentation of SCAD is sudden cardiac death and it can only be diagnosed in autopsy $[17,18]$. The diagnosis of SCAD can be made by coronary angiography among alive patients and the frequency of the disease is indicated as $0.1-1.1 \%$ [17, 19]. According to the data, among patients the dissection occurs in $70 \%$ of cases in the LAD, 20\% in the right coronary artery (RCA), $4 \%$ in the circumflex artery $(C X)$ and in less than $1 \%$ in the left main coronary artery (LMCA) [17]. Most of the patients are young to middle aged people who have no risk factors for coronary artery disease. Seventy percent of all cases are women and in $25-30 \%$ of these SCAD occurs in the peripartum period.

Spontaneous coronary artery dissection has been defined as dissection of the adventitia from the media of the coronary artery accompanied with or without rupture of the intima, resulting in accumulation of blood in this region in the absence of trauma or iatrogenic causes. As the tunica media dissects, the intimal layer is decompressed into the coronary artery lumen and causes occlusion. The clinical presentation of SCAD depends on the extent and severity of the coronary artery occlusion, and ranging from unstable angina to sudden cardiac death it can present with all types of acute coronary syndromes [16]. The physiopa-

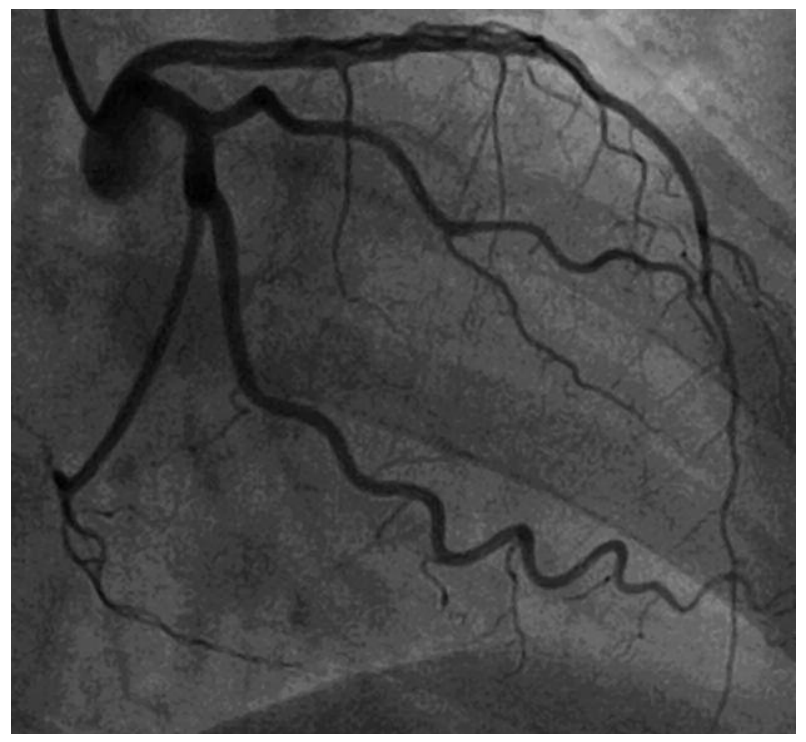

Fig. 2. Imaging of the left anterior descending dissection by conventional coronary angiography Ryc. 2. Obraz rozwarstwienia gatęzi przedniej zstępującej w tradycyjnej koronarografii 
thology of SCAD remains unclear. Abundant eosinophilic infiltration of the perivascular area is shown in the histopathological examination of the dissection region. Eosinophils release lytic enzymes. It is thought that these enzymes damage the intima and media layer and start the dissection. Another mechanism proposed to explain the underlying mechanism of spontaneous coronary artery dissection is intramedial haemorrhage caused by disruption with bleeding of the vasa vasorum $[17,20]$. Causes of SCAD have been observed in three groups of patients: those with coronary atherosclerosis, women in the peripartum period, and an idiopathic group. Oral contraceptives, cocaine abuse, recent chest trauma, Marfan syndrome, cystic medial necrosis, hypersensitivity vasculitis and vigorous exercise have been associated with $\operatorname{SCAD}[21,22]$.

Coronary angiography is the standard method to diagnose SCAD. latrogenic coronary artery dissection occurs in $0.2 \%$ of patients who undergo coronary angiography. Existence of a false lumen in angiography is pathognomonic. In coronary angiography, the passage of contrast material between two lumens (true and false lumen) in the media layer distinguished by a thin radiolucent intimal-medial flap is observed. Because contrast material fills the coronary artery wall, the coronary artery lumen can be seen larger. After wash-in of the coronary artery, persistent contrast enhancement may be observed. The compression of the true lumen by the false lumen can simulate stenosis. In the absence of intimal tear, dissection may not be evident. Also, if the true lumen severely narrows, the dissection becomes obscure. Clot filling the false lumen may simulate coronary thrombosis [2, 4]. Intravascular ultrasound is useful especially when the angiographic intimal-medial flap is obscure. It can also be used to differentiate between atherosclerotic coronary artery disease and coronary artery dissection and also to determine the morphology of the dissection [15]. Intravascular ultrasound can be used in the insertion of a guide wire into the true lumen, and evaluation of the diameter of the artery, length of the dissection and the occlusion of the dissection.

As reported in rare cases similar to our case, the diagnosis is made by coronary CT angiography. If used properly, coronary CT angiography can show high sensitivity for diagnosis of SCAD in patients with atypical chest pain, low cardiovascular risk and a weak positive treadmill exercise test. Recently, physicians often use CT angiography among the other tests, and along with coronary occlusion and coronary scoring dissection has to be screened as well. Although coronary angiography is the gold standard in the diagnosis of SCAD, CT angiography may also be considered as an alternative diagnostic method.

\section{References}

1. Waller BF. Nonatherosclerotic coronary heart disease. In: Hurst's the heart. Fuster V, Alexander RW, O'Rourke R, et al. (eds.). New York McGraw-Hill 2001; 1162-1168.
2. Vale PR, Baron DW. Coronary artery stenting for spontaneous coronary artery dissection: a case report and review of the literature. Cathet Cardiovasc Diagn 1998; 45: 280-286.

3. Pretty HC. Dissecting aneurysm of coronary artery in awoman aged 42. Br Med J 1931; 1: 667.

4. Hering D, Piper C, Hohmann C, et al. Prospective study of the incidence, pathogenesis and therapy of spontaneous, by coronary angiography diagnosed coronary artery dissection. Z Kardiol 1998; 87: 961-970.

5. Thompson EA, Ferraris S, Gres T, Ferraris V. Gender differences and predictors of mortality in spontaneous coronary artery dissection: a review of reported cases. J Invasive Cardiol 2005; 17: 59-61.

6. Celik SK, Sagcan A, Altintig A, et al. Primary spontaneous coronary artery dissections in atherosclerotic patients. Report of nine cases with review of the pertinent literature. Eur J Cardiothorac Surg 2001; 20: 573-576.

7. Kamran M, Guptan A, Bogal M. Spontaneous coronary artery dissection: case series and review. J Invasive Cardiol 2008; 20 : 553-559.

10. Azam MN, Roberts DH, Logan WF. Spontaneous coronary artery dissection associated with oral conraceptive use. Int J Cardiol 1995; 48: 195-198.

11. Kalaga RV, Malik A, Thompson PD. Exercise-related spontaneous coronary artery dissection: case report and literature review. Med Sci Sports Exerc 2007; 39: 1218-1220.

13. Bac DJ, Lotgering FK, Verkaaik APK. Spontaneous coronary artery dissection during pregnancy and postpartum. Eur Heart J 1995; 16: 136-138.

14. Tarhan A, Yapıcı F, Arslan Y, Özler A. Spontan koroner arter diseksiyonu: Olgu sunumu ile birlikte tıp literatürünün gözden geçirilmesi. Türk Kardiyol Dern Ars 2002; 30: 54-56.

15. Kearney P, Erbel R, Ge J, et al. Assessment of spontaneous coronary artery dissection by intravascular ultrasound in a patient with unstable angina. Cathet Cardiovasc Diagn 1994; 32: 58-61.

16. Dhawan R, Singh G, Fesniak H. Spontaneous coronary artery dissection: the clinical spectrum. Angiology 2002; 53: 89-93.

17. Jorgensen MB, Aharonian V, Mansukhani P, Mahrer PR. Spontaneous coronary dissection: a cluster of cases with this rare finding. Am Heart J 1994; 127: 1382-1387.

18. Thayer JO, Healy RW, Maggs PR. Spontaneous coronary artery dissection. Ann Thorac Surg 1987; 44: 97-102.

19. Hering D, Piper C, Hohmann C, et al. Prospective study of the incidence, pathogenesis and therapy of spontaneous, by coronary angiography diagnosed coronary artery dissection. Z Kardiol 1998; 87: 961-970.

20. Thompson EA, Ferraris S, Gres T, Ferraris V. Gender differences and predictors of mortality in spontaneous coronary artery dissection: a review of reported cases. J Invasive Cardiol 2005; 17: 59-61.

21. Conraads VM, Vorlat A, Colpaert CG, et al. Spontaneous dissection of three major coronary arteries subsequent to cystic medial necrosis. Chest 1999; 116: 1473-1475.

22. DeMaio J, Samuel J, Kinsella SH, Silverman ME. Clinical course and long-term prognosis of spontaneous coronary artery dissection. Am J Cardiol 1989; 64: 471-474.

23. Aqel RA, Zoghbi GJ, Iskandrian A. Spontaneous coronary artery dissection, aneurysms, and pseudoaneurysms: a review. Echocardiography 2004; 21: 175-182. 